\title{
Adherence of Bacteria to Pediatric Intravenous Catheters and Needles and Its Relation to Phlebitis in Animals
}

\author{
S. ASHKENAZI AND D. MIRELMAN
}

Department of Pediatrics, Beilinson Medical Center, Petah-Tiqva, Sackler School of Medicine, Tel Aviv University, Tel Aviv, Israel, and Department of Biophysics, Unit for Molecular Biology of Parasitic Diseases, Weizmann Institute of Science, Rehovoth, Israel

\begin{abstract}
The adherence of bacteria to pediatric IV catheters and needles was studied. Scanning electron micrographs showed that bacteria adhered well to the catheters and needles, mainly to non-smooth surface areas. In vitro quantitative determination, with the use of radiolabeled bacteria, revealed differences in the affinity of bacteria for the various IV cannula materials. The adherence per square area was greatest for plastic catheters, less for steel needles, and least for siliconized needles. Mean values for the adherence of Staphylococcus aureus to these cannulae were $37.9-40.3 \times 10^{5}$ bacteria $/ \mathrm{cm}^{2}$ for the plastic catheters; $10.2 \times 10^{5}$ bacteria $/ \mathrm{cm}^{2}$ for the steel needles, and $7.2-7.6 \times 10^{5} / \mathrm{cm}^{2}$ for the siliconized needles. Removal of the glutaraldehyde-fixed bacteria adhered to the cannulae, after their placement in veins of rabbits, was lower for the plastic catheters than the IV needles. The appearance and severity of venous phlebitis produced by the various cannulae was determined in an animal model. The degree of the inflammatory response elicited correlated with the in vitro bacterial adherence, indicating that bacterial adherence plays a role in the appearance of cannulaassociated phlebitis.

In view of our results and other previous observations of lower rate of infections with the use of IV needles, it is suggested that needles should be preferred to plastic catheters whenever possible. The described in vitro assay for bacterial adherence can be used to determine the adherent properties of IV cannulae, which should be considered in any future cannula design. (Pediatr Res 18:1361-1366, 1984)
\end{abstract}

Insertion of IV catheters and needles has become an integral part of pediatric care in hospitals, used for fluid replacement, administration of drugs, and monitoring of critically ill patients. Over one-fourth of hospitalized patients in the United States were found to receive IV infusions (8). This technique, however, has been associated with numerous complications, the most common of which is thrombophlebitis (5) followed sometimes by life-threatening septicemia. The infections can be caused by contaminated infusion solutions $(14,20)$, but they are more frequently related to contamination of the IV cannula (catheter or needle) where the microorganisms are partially shielded from the host defense mechanisms, can rapidly proliferate and initiate

Received September 20, 1983; accepted April 27, 1984

Requests for reprints should be addressed to Dr. S. Ashkenazi, Department of Biophysics, Weizmann Institute of Science, Rehovoth 76100, Israel.

This work was supported by a grant from the Rockefeller Foundation. infections. The bacteria can reach the cannula both at the moment of insertion and thereafter by migration along the interface between the cannula and the tissue.

Several studies have shown that steel needles ("scalp-vein needles") appear to be safer than plastic catheters, in relation to the frequency of cannula contamination as well as the appearance of thrombophlebitis and septicemia $(1,4,5,17)$. However, controlled comparative studies have not been performed, and the apparent safety of the IV needles may indeed be related to their use for shorter durations or in less severely ill patients, rather than to inherent properties of the needles as compared to the catheters.

In recent years evidence has been obtained that the adherence of bacteria to mammalian surfaces and medical devices is an important initial step in the infectious process $(10,16,23)$, and it was shown that bacteria are capable of adhering to IV catheters $(19,22)$. We therefore thought that it would be useful to quantitatively study bacteria adherence to various types of pediatric IV catheters and needles under controlled in vitro conditions, and to relate it to the appearance of phlebitis in an animal model.

\section{MATERIALS AND METHODS}

Bacteria. Clinical isolates of bacteria, which are frequently found in cannula-related infections and isolated from foreign body infections, were identified by standard microbiological techniques (7). The bacteria tested were: Staphylococcus aureus coagulase-positive encapsulated strain and Serratia marcescens (obtained from S. Katz, Hadassah Medical Center, Israel), Klebsiella pneumoniae (obtained from M. Weinstein, Beilinson Medical Center, Israel), and Escherichia coli $0115: \mathrm{K} 4$ (clinical isolate 7343, obtained from Dr. G. Altmann, Tel-Hashomer Hospital, Israel). All Gram-negative organisms were fimbriated strains. $S$. aureus were grown in $0.5 \%$ peptone (Difco Laboratories, Detroit, $\mathrm{MI})$, and $E$. coli, $S$. marcescens, and $K$. pneumoniae were grown in $1 \%$ peptone, $0.5 \%$ yeast extract and $0.5 \% \mathrm{NaCl}$.

Preparation of radiolabeled bacteria. Sixteen hours prior to each experiment, bacteria were transferred from stock agar slants to freshly prepared respective media $(15 \mathrm{ml})$ with the addition of $200 \mu \mathrm{l} \mathrm{D}-\left[{ }^{14} \mathrm{C}\right]$ glucose $(0.1 \mathrm{mCi} / \mathrm{ml}, 239 \mathrm{mCi} / \mathrm{mmol}$; The Radiochemical Centre, Amersham, England), and incubated at $37^{\circ} \mathrm{C}$. The bacteria were harvested by centrifugation $(9000 \times g, 10$ $\min$ ), and washed three times by suspension in saline and sedimentation as above. The sedimented bacteria were resuspended in saline; their concentration was adjusted photometrically to give a stock solution of $10^{\circ}$ bacteria/ml, from which a series of 1:5 dilutions were prepared for the various experiments. The radioactivity of the labeled bacteria was counted in a Tricarb liquid scintillation spectrometer (model 3255, Packard Instru- 
ments, Downers Grove, IL) with $10 \mathrm{ml}$ Triton X-100-toluene scintillation fluid. The usual specific radioactivity obtained was $1 \mathrm{cpm} / 1-2 \times 10^{3}$ bacteria. Precipitation in $5 \%$ trichloroacetic acid showed that more than $90 \%$ of the radiolabeled precursor was incorporated into macromolecular components of the bacteria. Glutaraldehyde-fixed radiolabeled bacteria were prepared by resuspension of the washed bacterial sediment in $0.2 \%$ glutaraldehyde in isotonic saline and incubation for $20 \mathrm{~min}$. The bacteria were sedimented $(9000 \times g, 10 \mathrm{~min})$, washed three times with $0.1 \mathrm{M}$ glycine in isotonic saline and finally resuspended in saline to the desired concentration. No growth was observed upon culturing these glutaraldehyde-fixed bacteria on agar plates.

$I V$ catheters and needles. Catheters and needles routinely used in pediatric practice were examined. They included: $(a)$ siliconized steel needles, size 21 and 25 gauge (Deseret Pharmaceutical Co., Sandy, UT; $(b)$ steel needles, size 21 and 25 gauge (Migada, Rehovoth, Israel); (c) Teflon catheters, size 22 and 24 gauge (Quick-Cath, Travenol Laboratories, Deerfield, IL); and (d) Teflon catheters size 19 gauge (Venflon, Viggo AB, Helsingborg, Sweden). The outer and inner diameters of the cannulae tested were obtained from the manufacturers and verified by measuring them with a technical microscope (model 5-A, Hauser, Bienne, Switzerland).

Assay for in vitro bacterial adherence to IV catheters and needles. Pediatric catheters (segments of $2.0-\mathrm{cm}$ length, after sterile cut) and needles (the whole needle, without the connecting plastic tube) were preincubated in $4 \mathrm{ml}$ sterile isotonic saline $\left(37^{\circ}\right.$ C, $60 \mathrm{~min}$ ) in $60 \times 15 \mathrm{~mm}$ Petri dishes (Falcon Plastics B-D) and agitated in an incubation shaker (New Brunswick Scientific, Edison, $\mathrm{NJ})$ at $100 \mathrm{rpm}$. Radiolabeled bacteria $\left(1 \mathrm{ml}, 10^{6}-10^{9}\right.$ bacteria/ml, depending on the experiment) were added to the Petri dishes and incubated with the IV cannulae for 20-100 min $\left(37^{\circ} \mathrm{C}, 100 \mathrm{rpm}\right)$. The cannulae, always tested in duplicates, were picked up with sterile fine forceps and washed five times in sterile saline solution to remove the nonadhered bacteria. This washing procedure was found to be satisfactory, since no further release of radiolabeled bacteria was observed by additional washing. The number of the adhered bacteria was determined by counting the radioactivity of the incubated cannulae in 20 -ml vials, as described above. The number of the bacteria adhered to the incubated cannula was divided by its calculated surface area $[3.14 \times$ (cannula diameter) (cannula length)] to obtain the bacteria adhered per $\mathrm{cm}^{2}$ of the cannula examined, which was compared among the various catheters and needles tested, expressing the affinity of bacteria for the different cannula materials.

In order to follow the in vivo situation, in some experiments we preincubated the cannulae in sterile whole blood $(4 \mathrm{ml})$ and compared the results to preincubation with saline. In other experiments, unlabled bacteria ( $S$. marcescens, $1-2 \times 10^{9} / \mathrm{ml}$ ) were added to the incubating solution with the radiolabeled $S$. aureus, to find out whether competition plays a role in the adherence process.

Since the IV lengths and surface areas of the various cannulae were different, it seemed important to determine not only the adherence per unit area, but also the adherent capability of the whole IV portion of the cannulae. This was determined by multiplying the adherence per $\mathrm{cm}^{2}$ by the calculated IV surface area. The adherence index of each cannula was defined as the adherence to its IV surface area divided by that of a 25 gauge siliconized needle (Deseret), which was the lowest and defined as one unit.

In vivo studies with an animal model. Male albino rabbits (weight, 2-3 kg) were used in these experiments. IV catheters and needles were aseptically inserted into the marginal vein of the animal's ear, after shaving the hair over that area and cleaning it with $70 \%$ ethyl alcohol. The cannula was securely anchored to prevent any motion, and sterile saline solution was infused through it in a constant rate $(2 \mathrm{ml} / \mathrm{h})$ using a Pediatric Voluset (model VS-40, Migada, Rehovoth, Israel; 60 drops/ml), while the animal continued to drink and eat regularly. Preliminary examinations showed that no local or systemic changes occurred during cannulation for a follow-up period of $72 \mathrm{~h}$.

In order to induce cannula-related phlebitis in the animal, a bacterial suspension of $S$. aureus $\left(0.1 \mathrm{ml}, 5 \times 10^{9}\right.$ bacteria $\left./ \mathrm{ml}\right)$ was applied to the skin at the site of cannula insertion. This procedure produced venous phlebitis, extending beyond the cannula tip, and we were able to culture the $S$. aureus from the cannula, using the semiquantitative method (15). The infectivity of the various pediatric IV cannulae was determined by inserting them into the animal vein and recording the local phlebitic response after $72 \mathrm{~h}$, which was classified according to three grades: 0 , no changes; 1 , mild phlebitis with redness, swelling, and induration; 2 , severe inflammation with suppuration. In all the experiments, cannulae were inserted into the veins of both ears, but bacteria were applied only to one ear, the other served as a control.

In a second type of experiment, we studied the in vivo removal rate of the adhered bacteria from the various cannulae. Cannulae were incubated with inert glutaraldehyde-fixed radiolabeled bacteria, and were then inserted into the animal's vein. The radioactivity of the adhered bacteria was determined after the in vitro assay, before insertion into the animal, as well as following removal of the cannulae from the animal, after 1,2 , or 3 days. The removal rate of bacteria from the different cannulae was compared.

Scanning electron microscopy. Pediatric IV catheters and needles were incubated with suspension of $S$. aureus $\left(37^{\circ} \mathrm{C}, 100\right.$ min, $100 \mathrm{rpm}$ ), washed and fixed with $2 \%$ glutaraldehyde solution (room temperature, $60 \mathrm{~min}, 100 \mathrm{rpm}$ ). After washing in 0.1 sodium cacodylate buffer ( $\mathrm{pH} 7.2$ ) and incubation in $1 \%$ osmium tetraoxide (30 $\mathrm{min}$ ), the cannulae were washed again, dehydrated with increasing concentrations of alcohol and dried to a critical point. The cannulae were then fixed to metal planchets, coated with gold, and examined with a scanning electron microscope (model JSM-35C, JEOL, Japan).

\section{RESULTS}

In vitro bacterial adherence. Adherence of bacteria to the IV catheters and needles was clearly demonstrated by the scanning electron micrographs. Different types of irregularities were observed (Fig. 1) on the internal and external surfaces of all the cannulae examined. Bacteria adhered easily to these irregularities, sometimes forming small colonies (Fig. 2), but adhered bacteria were also seen on rather smooth areas of the surface of the cannulae examined.

Quantitative assay with radiolabeled bacteria showed that the adherence was temperature (optimal $37^{\circ} \mathrm{C}$ ) and time dependent (Fig. 3). The adherence was minimal after 10-min incubation, and increased gradually with time.

The number of bacteria adhered to the catheters and needles increased when the concentration of $S$. aureus in the incubating suspension was higher (Fig. 4). Similar results were obtained in suspensions of $E$. coli and $K$. pneumoniae.

The quantitative adherence of bacteria to the various pediatric cannulae is summarized in Table 1 . It was found that bacteria adhered differently to the various cannula materials under the same experimental conditions. The adherence of $S$. aureus (per $\mathrm{cm}^{2}$ ) was lowest to siliconized needles, slightly higher to steel needles and about seven times higher to IV catheters, although experimental variations were found. The adherence to different size catheters of the same manufacturer was very similar. Differences in the adherent capabilities of the various bacteria examined were also noticed (Table 1), but the trend of increased adherence (per unit area) to the catheters, as compared to the needles, remained.

The adherence index, indicating the adherent capability of the whole IV surface area of the cannula, showed even greater differences: the index of the IV catheters was up to 17.3 times higher than the small siliconized needle (Fig. 5). The adherence 

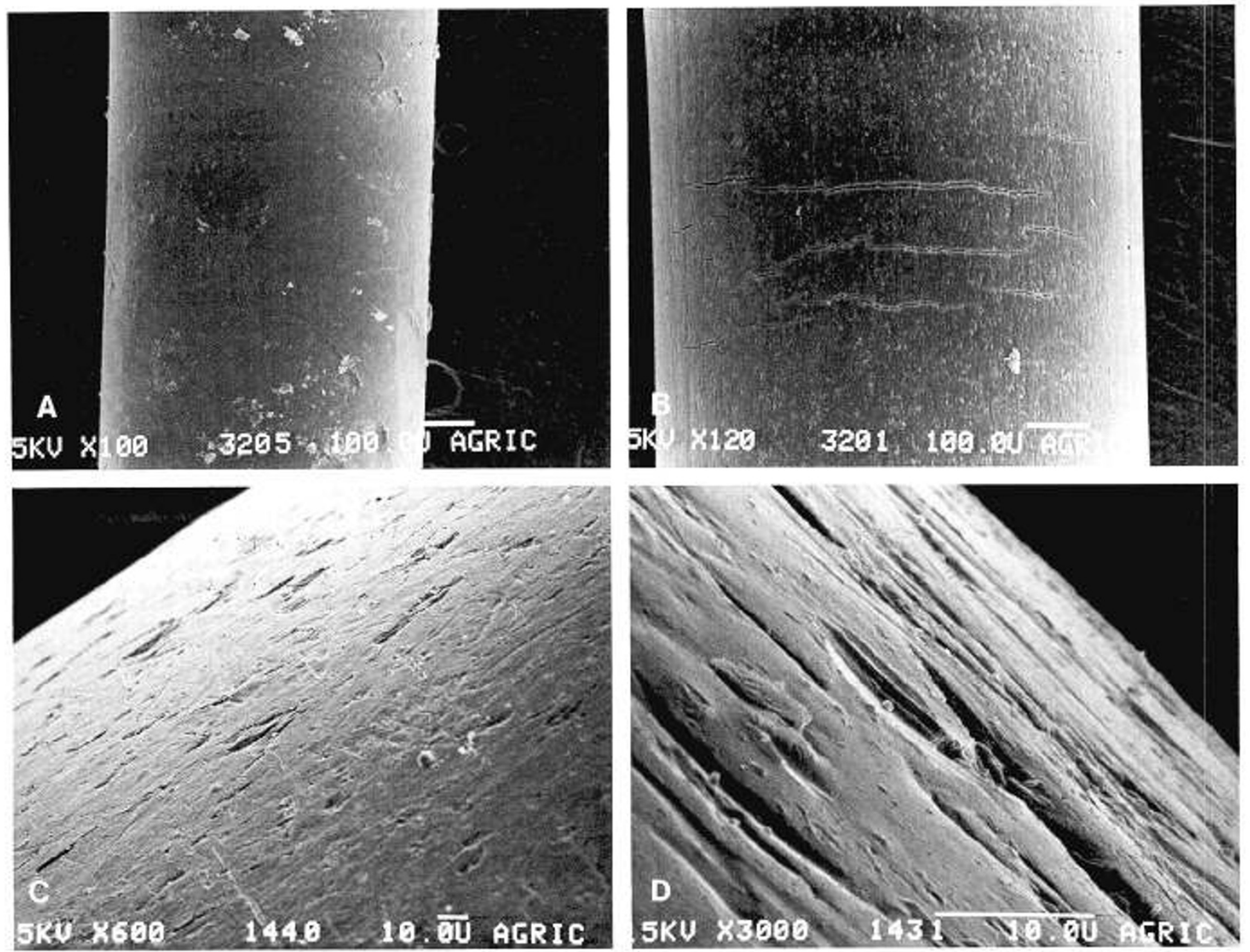

Fig. 1. Scanning electron micrographs of various pediatric IV cannulae, showing different types of irregularities on the surface area of all the cannulae examined. $A$, Deseret siliconized needle 25 gauge $(\times 100)$; $B$, Quick-Cath catheter 22 gauge $(\times 120)$; $C$, Migada needle 21 gauge $(\times 600)$; $D$, Venflon catheter, 19 gauge $(\times 3000)$.

index of the catheters was greater both as a result of increased adherence per unit area and a greater IV surface area.

Preincubation of the cannulae in sterile whole blood, instead of saline caused about $40 \%$ increase in the number of bacteria adhered to the IV catheters and needles. Addition of unlabeled bacteria ( $S$. marcescens) to the incubating solution inhibited the adherence of radiolabeled $S$. aureus (Fig. 6) to the catheters and needles. No differences in the adherence to the various cannulae were found between the glutaraldehyde-fixed and the viable bacteria.

In vivo studies with an animal model. It was possible to produce cannula-related venous phlebitis in the animal by the procedure described above. The various pediatric IV catheters and needles were inserted into the animal vein and the degree of inflammation was recorded. Different IV cannulae elicited different degrees of inflammatory reaction (Table 2). The "infectivity score," an indicator of the infective properties of the various cannulae, was higher for the IV catheters than the needles, in correlation with the adherence index determined in vitro.

Cannulae to which glutaraldehyde-fixed radiolabeled bacteria ( $S$. aureus) were adhered did not cause any infection. In vitro incubation of these cannulae for 3 days did not affect the number of bacteria adhered. Removal of these cannulae from the animal after 1,2 , or 3 days and counting the bacteria still adhered indicated the in vivo removal rate of bacteria from the IV cannulae. Higher percentage of the adhered bacteria were re- moved from the IV needles compared to the catheters $(60 \%$ versus $38 \%$, respectively; Fig. 7), but still a significant percentage of the adhered bacteria remained attached to the IV cannulae, apparently due to shielding from the host defense mechanisms.

\section{DISCUSSION}

Previous studies using culture methods have shown that bacteria adhered to IV catheters $(19,22)$. In the present study bacterial adherence to IV catheters and needles, which are routinely used in pediatric practice, was quantitatively determined by the use of radiolabeled bacteria. Our results show that bacteria, which are usually associated with cannula-related infections, adhere with different affinity to the various types of cannula materials, under the same in vitro experimental conditions. The adherence (per $\mathrm{cm}^{2}$ ) was greatest to plastic catheters and least to siliconized needles. Moreover, since the IV surface area of the various cannulae is different, the adherent capability of the whole IV surface area was determined. This shows even higher differences: the adherence to IV catheters is 11.1 to 17.3 times higher than the adherence to the small siliconized needle (Fig. 5).

The removal of adhered bacteria from the cannulae by the host defense mechanisms, after their insertion into the animal vein, was limited. However, the removal from the IV catheters, which previously adhered more bacteria, was lower than from the needles ( $38 \%$ versus $60 \%$ ). 

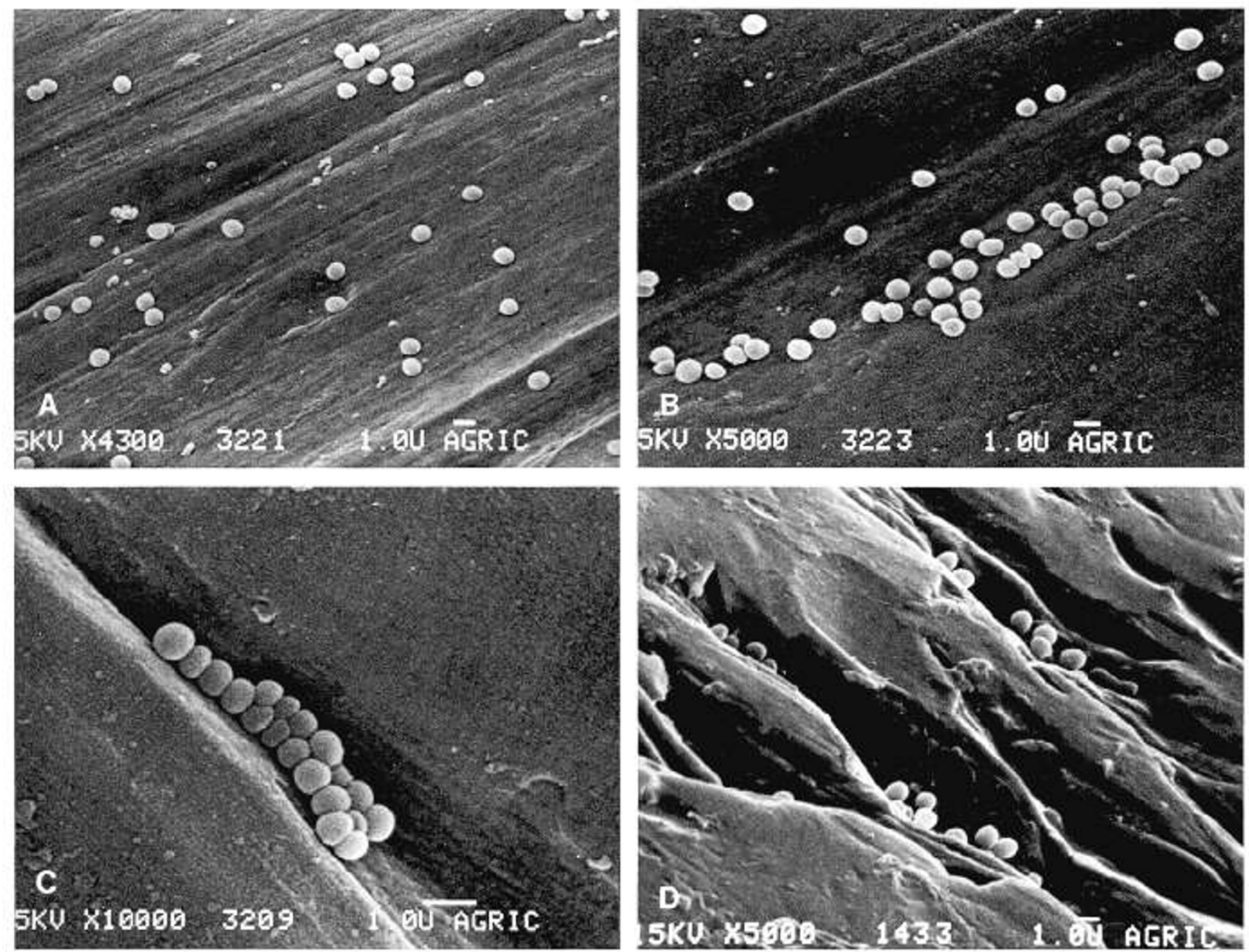

Fig. 2. Adherence of $S$. aureus to IV cannulae as seen by scanning electron microscopy. The experimental conditions and the preparations of the samples are detailed in the text. $A$, Deseret siliconized needle $(\times 4,300) ; B$, quick-Cath catheter $(\times 5,000) ; C$, Migada needle $(\times 10,000) ; D$, Venflon catheter $(\times 5,000)$.

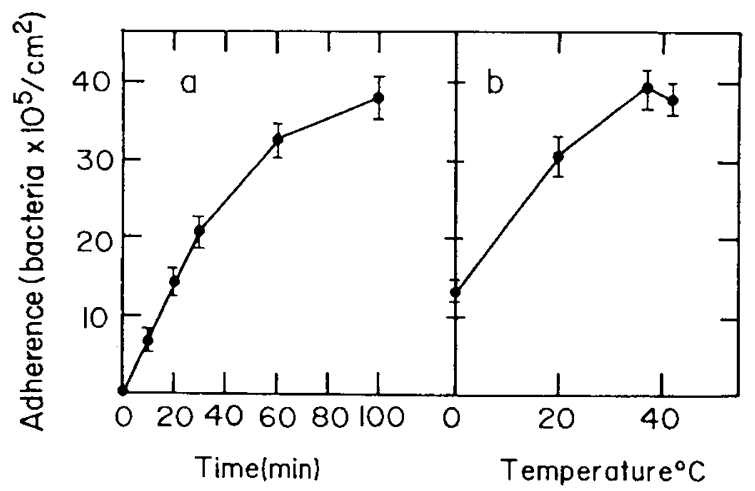

Fig. 3. Time $(a)$ and temperature $(b)$ dependence of the adherence of $S$. aureus $\left(10^{9}\right.$ bacterial $\left./ \mathrm{ml}\right)$ to IV catheter (Quick-Cath 22 gauge), incubated at $37^{\circ} \mathrm{C}(a)$, for $100 \mathrm{~min}(b)$. Results represent means \pm SEM of three determinations.

The mechanisms of bacterial adherence to IV cannulae has not as yet been clarified. Scanning electron micrographs showed that bacteria attached to irregularities, found on all the cannulae that were examined by us (Fig. 2). However, bacteria also adhered to the rather smooth parts of the cannulae surfaces, in accordance with the observations of Locci et al. (12). Differences were also found between the adherent capabilities of the various types of bacteria examined.

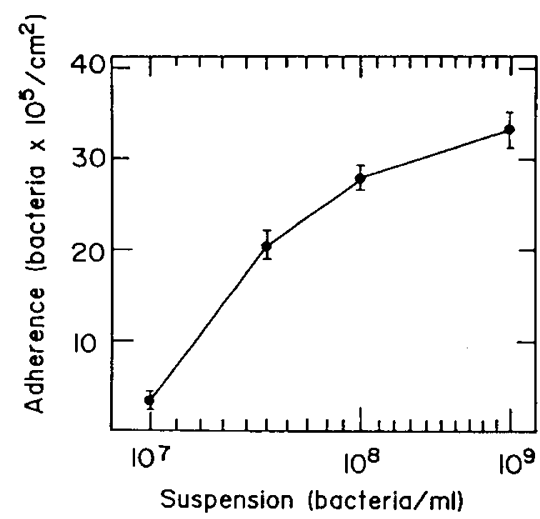

Fig. 4. Adherence of $S$. aureus to IV catheter (Quick-Cath 22 gauge) incubated $37^{\circ} \mathrm{C}, 100 \mathrm{~min}, 100 \mathrm{rpm}$ ) with bacterial suspension of different concentrations. Results represent means \pm SEM of three determinations.

The mechanism of the adherence is currently under investigation in our laboratory. We have observed that bacterial hydrophobicity, which was shown to play a role in adherence to biomaterials (9) and measured by adherence to hydrocarbons (21), is apparently important. Preliminary results indicate that cell surface hydrophobicity of the $S$. aureus and $S$. marcescens strains used in this study was much higher than that of the $E$. coli strain, which indeed adhered less well (Ashkenazi et al., 
Table 1. Adherence of bacteria to IV catheters and needles*

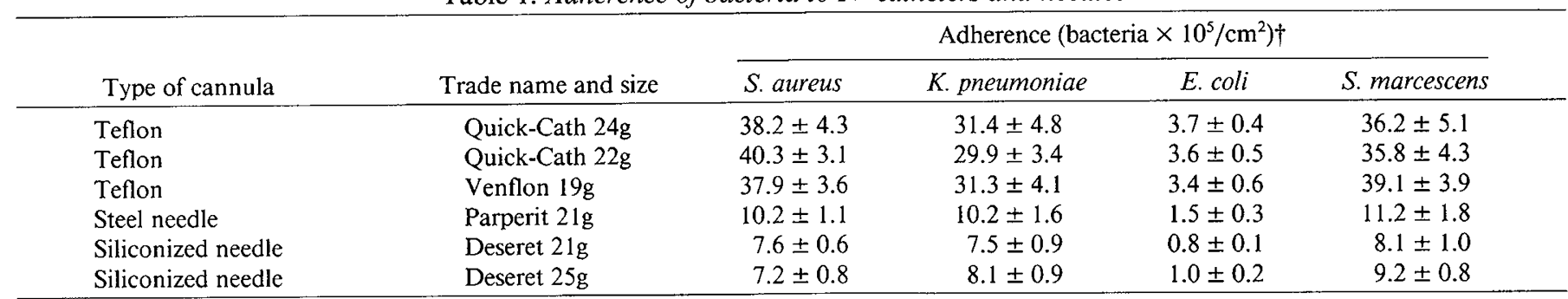

* The adherence was determined under the standard experimental conditions ( $10^{9}$ bacteria $\left./ \mathrm{ml}, 37^{\circ} \mathrm{C}, 100 \mathrm{~min}, 100 \mathrm{rpm}\right)$. g, gauge.

$\dagger$ Results represent means \pm SEM of 20 determinations for $S$. aureus, and of six determinations for the other bacteria.

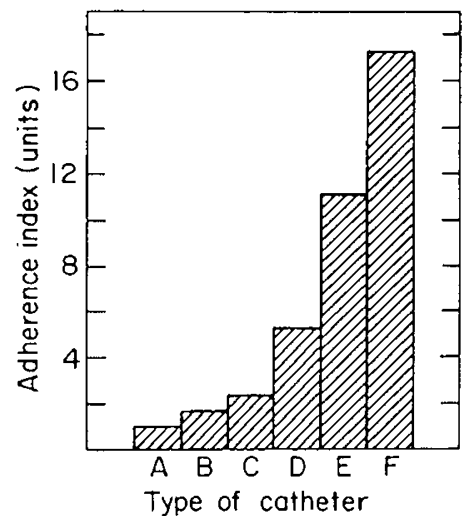

Fig. 5. Comparative adherence of $S$. aureus to IV surface area of different cannulae in units (adherence to 25 gauge siliconized needle, $A$ $=1$ unit; $B=21$ gauge siliconized needle (Deseret); $C=21$ gauge needle (Migada); $D=24$ gauge catheter (Quick-Cath); $E=22$ gauge catheter (Quick-Cath); $F=19$ gauge catheter (Venflon).

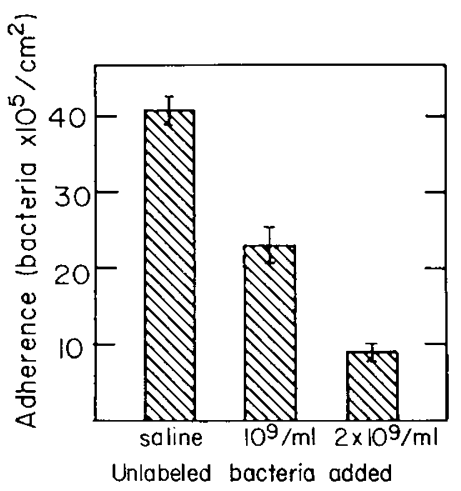

Fig. 6. Inhibition of the adherence of radiolabeled $S$. aureus $\left(10^{9}\right.$ bacteria) to IV catheter (Quick-Cath 22 gauge) by the addition of unlabeled $S$. marcescens $\left(1-2 \times 10^{9}\right)$ to the incubating solution. Results represent means \pm SEM of three determinations, under the standard assay conditions $\left(37^{\circ} \mathrm{C}, 100 \mathrm{~min}, 100 \mathrm{rpm}\right)$.

manuscript in preparation). The adherence to the cannulae material is probably a nonselective process, as indicated by competition between the different bacteria. Another possible factor was suggested by Christensen et al. $(2,3)$ who have shown that the production of slime may be an important factor for adherence to solid surfaces and production of infections. Preincubation of the IV cannulae with sterile whole blood, instead of saline, augmented the adherence of bacteria. This can be explained by previous observations that a fibrin sleeve usually covered the catheters after their insertion (18) and that bacteria can attach to fibrin cloths (6). Bacteria that adhered to IV catheters have been shown to multiply (19).

In order to evaluate the applicability of the in vitro findings to the in vivo situation, we have examined the ability of the various cannulae to produce venous phlebitis in an animal model. Our
Table 2. The production of venous phlebitis by the IV cannulae in an experimental model*

\begin{tabular}{lcccc}
\hline & \multicolumn{2}{c}{ Degree of inflammatory response } & Infectivity \\
\cline { 2 - 5 } Cannula type $\dagger$ & 0 & 1 & 2 & score \\
\hline Catheter & & $9: 10$ & $1: 10$ & 11 \\
Needle & $4: 10$ & $6: 10$ & & 6 \\
\hline
\end{tabular}

* Venous phlebitis was elicited in rabbits after insertion of the cannulae to their marginal vein of the ear, and the degree of the inflammatory response was recorded after $72 \mathrm{~h}$. Twenty rabbits were used, 10 for each cannula. The detailed experimental conditions are explained in the text.

$\dagger$ Catheter, Quick-Cath 22 gauge needle. Needle, siliconized needle, 21 gauge.

$\$$ Infectivity score is the summation of the degree of inflammatory response found in the rabbits.

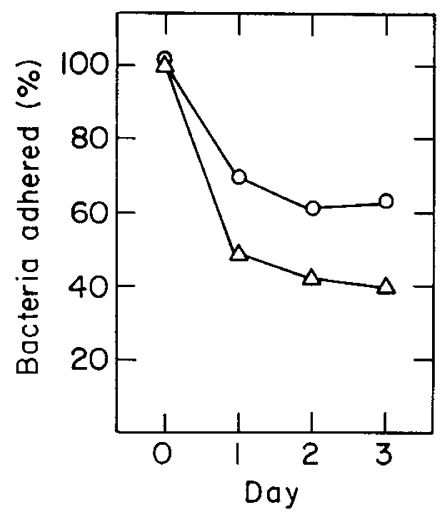

Fig. 7. Removal of glutaraldehyde-fixed $S$. aureus adhered to IV cannulae following their placement in veins of rabbit. For further details see the text. Adherence before insertion into the animal $=100 \%$. In vitro incubation of the cannulae with the glutaraldehyde-fixed adhered bacteria for 3 days had no effect on the number of the adhered bacteria. $O$, catheter (22 gauge Quick-Cath); $\Delta$, siliconized needle (21 gauge Deseret).

results indicate that the degree of the inflammatory response in the animal correlates well with the adherent capability of the various cannulae. These findings are in accordance with previous observations that both local thrombophlebitis and septicemia in humans are more frequent with the use of catheters than IV steel needles $(4,11,13,17)$. Since the development of cannulaassociated infections is affected by multiple factors, such as duration of cannulation, its location, type of infusion fluid, and host defense mechanisms, it was not clear whether the different rates of infections are related to inherent properties of the cannulae. Our findings indicate that the adherent properties of the IV cannulae, which are dependent on physical, structural, and chemical properties, may play a role in the appearance and severity of inflammation associated with their use.

In view of the present findings, together with previous observations in children that IV needles were less frequently complicated by infections (17), it is suggested that IV needles should be used whenever possible, especially in infants, where they can 
easily be introduced into scalp veins. Indiscriminate use of plastic catheters, solely for convenience, should be discouraged. However, catheters are generally more secure, and may be indicated in critically ill children for administration of drugs and fluids and for monitoring.

Further investigations are needed in order to clearly understand the mechanisms of bacterial adherence to IV cannulae and to devise ways to prevent it. Our assay for in vitro bacterial adherence to cannulae can be used in order to help to produce better designed cannulae, with minimal adherent properties and inflammatory complications.

\section{REFERENCES}

1. Banks DC, Yates DB, Cawdrey HM, Harries MG, Kidner PH 1970 Infection from intravenous cathers. Lancet $1: 443$

2. Christensen GD, Simpson WA, Bisno AL, Beachey EH 1982 Adherence of slime-producing strains of Staphylococcus epidermidis to smooth surfaces. Infect Immun 37:318

3. Christensen GD, Simpson WA. Bisno AL, Beachey EH 1983 Experimental foreign body infections in mice challenged with slime-producing Staphylococcus epidermidis. Infect Immun 40:407

4. Crossley K. Matsen JM 1972 The scalp vein needle: a prospective study of associated complications. J Am Med Assoc 220:985

5. Druskin MS, Siegel PD 1963 Bacterial contamination of indwelling intravenous polyethylene catheters. J Am Med Assoc 185:966

6. Dunn DL, Simmons RL 1982 Fibrin in peritonitis. III. The mechanism of bacterial trapping by polymerizing fibrin. Surgery $92: 513$

7. Finegold SM. Martin WJ, Scott EG 1978 Diagnostic Microbiology, 5th ed. The CV Mosby Company. St. Louis, p 123

8. Francke DE (ed) 1970 Handbook of IV Additive Reviews. Hamilton Press, Hamilton, IL, $\mathrm{p} 18$

9. Hogt AH, Dankert J, Feijen J, DeVries JA 1982 Cell surface hydrophobicity of Staphylococcus species and adhesion onto biomaterials. Antonie Van Leeuwenhoek 48:496

10. Katz S, Izhar M, Mirelman D 1981 Bacterial adherence to surgical sutures: a possible factor in suture induced infection. Ann Surg 194:35

11. Kaye W 1982 Catheter- and infusion-related sepsis: the nature of the problem and its prevention. Heart Lung 11:221

12. Locci R, Peters G, Pulverer G 1981 Microbial colonization of prosthetic devices. III. Adhesion of staphylococci to lumina of intravenous catheters perfused with bacterial suspension. Zentralbl Bakteriol B 173:300

13. Maki DG. Goldmann DA, Rhame FS 1973 Infection control in intravenous therapy. Ann Intern Med 79:867

14. Maki DG, Rhame FS, Mackel DC, Bennett JV 1976 Nationwide epidemic of septicemia caused by contaminated intravenous products: epidemiologic and clinical features. Am J Med 60:471

15. Maki DG, Weise CE. Sarafin HW 1977 A semiquantitative culture method for identifying intravenous-catheter-related infection. N Engl J Med 296:1305

16. Mirelman D, Katz S, Izhar M, Kobiler D 1981 Adherence of pathogenic microorganisms to the intestinal tract. In: Slutzky GM (ed) The Biochemistry of Parasites. Pergamon Press, Oxford, p 103

17. Peter G, Lloyd-Still JD, Lovejoy FH Jr 1972 Local infection and bacteremia from scalp vein needles and polyethylene catheters in children. J Pediatr 80:78

18. Peters WR, Bush WH, McIntyre RD, Hill LD 1973 The development of fibrin sheath on indwelling venous catheters. Surg Gynecol Obstet 137:43

19. Peters G, Locci R, Pulverers G 1982 Adherence and growth of coagulasenegative staphylococci on surfaces of intravenous catheters. J Infect Dis $146: 479$

20. Phillips I, Eykyn S, Laker M 1972 Outbreak of hospital infection caused by contaminated autoclaved fluids. Lancet 1:1258

21. Rosenberg M, Gutnick D, Rosenberg E 1980 Adherence of bacteria to hydrocarbons: a simple method for measuring cell-surface hydrophobicity. FEMS Microbiol Lett 9.29

22. Sheth NK. Rose HD, Franson TR. Buckmire FLA, Sohnle PG 1983 In vitro quantitative adherence of bacteria to intravenous catheters. J Surg Res 34:213

23. Sugarman B 1982 In vitro adherence of bacteria to prosthetic vascular grafts. Infection 10:9

\title{
The Effect of Postnatal Age on the Adherence of Shigella flexneri, Escherichia coli 0124, and $E$. coli 0128 to Guinea Pig Intestinal Cells
}

\author{
S. ASHKENAZI AND D. MIRELMAN \\ Department of Pediatrics, Beilinson Medical Center, Petah Tiqva, Sackler School of Medicine, Tel Aviv \\ University, Tel Aviv, Israel, and Department of Biophysics, Unit for Molecular Biology of Parasitic Diseases, \\ Weizmann Institute of Science, Rehovoth, Israel
}

\begin{abstract}
Since postnatal development of the gastrointestinal tract has an important effect on its microbial flora and may influence the types of intestinal infections, we examined the effect of age on bacterial adherence to intestinal epithelial cells. Radiolabeled bacteria were incubated with guinea pig enterocytes released by treating loops of the intestine with solutions containing EDTA, dithiothreitol, and citrate. Nonbound bacteria were separated from intestinal cells by sedimentation on a Percoll gradient. The colonic cells avidly bound Shigella flexneri (64 bacteria per cell), Escherichia coli 0124 (59), and E. coli 0128 (53).
\end{abstract}

Received August 22, 1983: accepted April 19, 1984

Requests for reprints should be addressed to D. Mirelman, Department of Biophysics, Weizmann Institute of Science, Rehovoth 76100, Israel.

This investigation was supported by a grant from the Rockefeller Foundation.
The adherence process was $\mathrm{Ca}^{2+}$ and temperature dependent, was inhibited by fucose, glucose, and mannose, and was shown to be mediated by a carbohydrate-binding protein (lectin) on the colonic cells. Adherence of these bacteria to intestinal cells of newborn animals was only 15$25 \%$ of the adherence to adult animal cells and increased gradually, reaching adult values at about 2 weeks of age. The lectin activity, which was determined by agglutination of bacteria, was secreted with the colonic mucus. It was undetectable in the newborn animal, appeared gradually with age, and its titer correlated with the adherent capability of the colonic cells.

$E$. coli 0128 was the only one of the bacteria tested which significantly adhered to the ileum (19 bacteria per cell) in a process inhibited by mannose. This adherence 